\title{
CUTTING TESTING COSTS BY THE POOLING DESIGN
}

\author{
Dimitrije D. Čvokić \\ University of Banja Luka, Faculty of Sciences and Mathematics, Banja \\ Luka, Republic of Srpska, Bosnia and Herzegovina, \\ e-mail: dimitrije.cvokic@pmf.unibl.org, \\ ORCID ID: (1)https://orcid.org/0000-0001-7975-4224
}

DOI: 10.5937/vojtehg68-28078; https://doi.org/10.5937/vojtehg68-28078

FIELD: Mathematics

ARTICLE TYPE: Original scientific paper

\begin{abstract}
:
Introduction/purpose: The purpose of group testing algorithms is to provide a more rational resource usage. Therefore, it is expected to improve the efficiency of large-scale COVID-19 screening as well.

Methods: Two variants of non-adaptive group testing approaches are presented: Hwang's generalized binary-splitting algorithm and the matrix strategy.

Results: The positive and negative sides of both approaches are discussed. Also, the estimations of the maximum number of tests are given. The matrix strategy is presented with a particular modification which reduces the corresponding estimation of the maximum number of tests and which does not affect the complexity of the procedure. This modification can be interesting from the applicability viewpoint.

Conclusion: Taking into account the current situation, it makes sense to consider these methods in order to achieve some resource cuts in testing, thus making the epidemiological measures more efficient than they are now.
\end{abstract}

Key words: pooling design, group testing, Hwang's generalized binary-splitting algorithm, matrix strategy, COVID-19, SARS-CoV-2.

\section{Introduction}

The COVID-19 pandemic, caused by the SARS-CoV-2 virus, has posed a challenge to many countries when it comes to detecting infected people as a basis for implementing appropriate epidemiological measures. The high $R_{0}=5.7$ value of the SARS-CoV-2 virus (Sanche et al, 2020) affected the increased demand for tests (Pfeiffer et al, 2020), which was, according to some media reports in Serbia (Blic, 2020), also accompanied by the distribution problems. In other words, testing can quickly become a bottleneck in the event of a massive disease outbreak. 
Modern epidemiological measures are proactive. In order to control the spread of infection, it is important to detect:

- pre-symptomatic cases;

- infected persons who have many high-risk social contacts (e.g., medical staff, geriatric center workers, teachers, etc.).

The mass testing allows observing and tracking epidemiological patterns as the infection spreads. The situation mentioned above in which testing becomes a bottleneck certainly requires some optimization.

Among the SARS-CoV-2 virus infection tests, the most well-known methods are RT-(q)PCR and serological antibody tests. The RT-(q)PCR test is considered the most accurate (the most reliable). On the other hand, these tests are more expensive and complex when it comes to equipment, time, trained personnel, and procedural complexity.

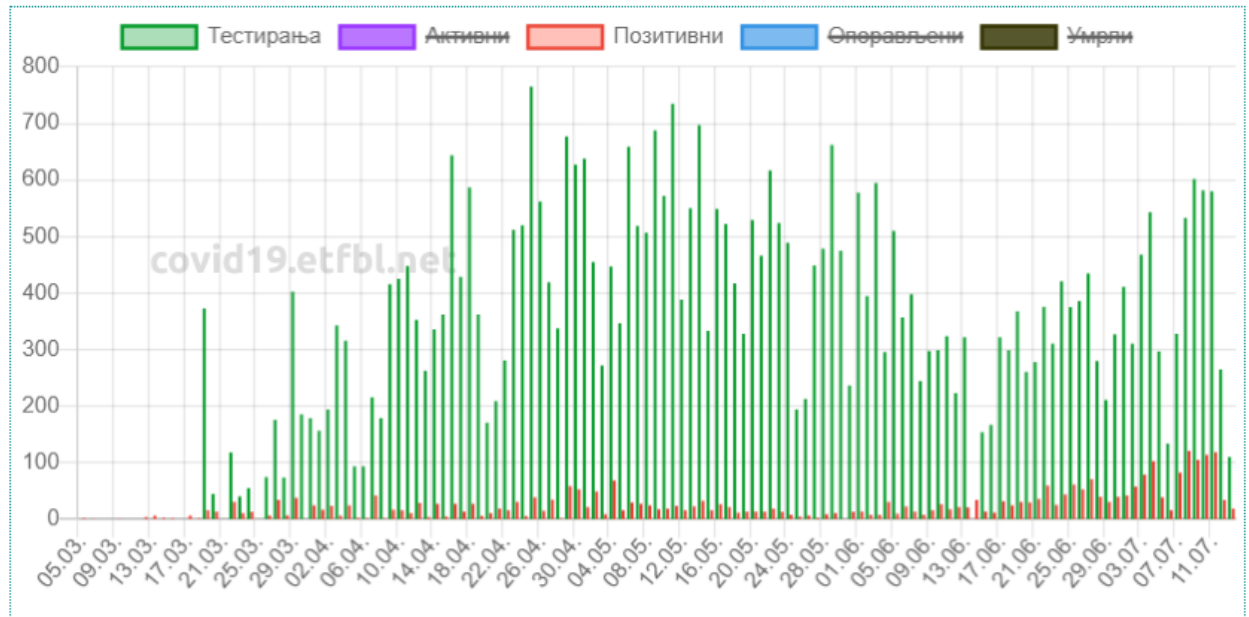

Figure 1 - Total number of tested (green) and confirmed (red) cases per day, for Republic of Srpska, until July 11th, 2020 (Faculty of Electrical Engineering in Banja Luka, 2020)

Puc. 1 - Общее количество протестированных (зеленый цвет) и подтвержденных (красный цвет) случаев на ежедневной основе в Республике Сербской, до 11 июля 2020 года (Faculty of Electrical Engineering in Banja Luka, 2020)

Слика 1 - Преглед односа укупног броја тестираних (зелена боја) и потврђених (црвена боја) случаејва по данима, за Републику Српску, до 11. јула 2020. (Faculty of Electrical Engineering in Banja Luka, 2020) 
According to the reports of the official portal of the Government of Republic of Srpska (Government of Republic of Srpska, 2020), in the Republic of Srpska the percentage of confirmed cases (relative to the number of tests, daily) took an upward trend. In Figure 1, there is a time series bar plot depicting values that correspond to the number of confirmed cases (red) and the number of conducted tests (green), until July 11th, 2020. Given the test cost and the increased workload of laboratory technicians, it is reasonable to consider some strategies that will save both the testing kits and time.

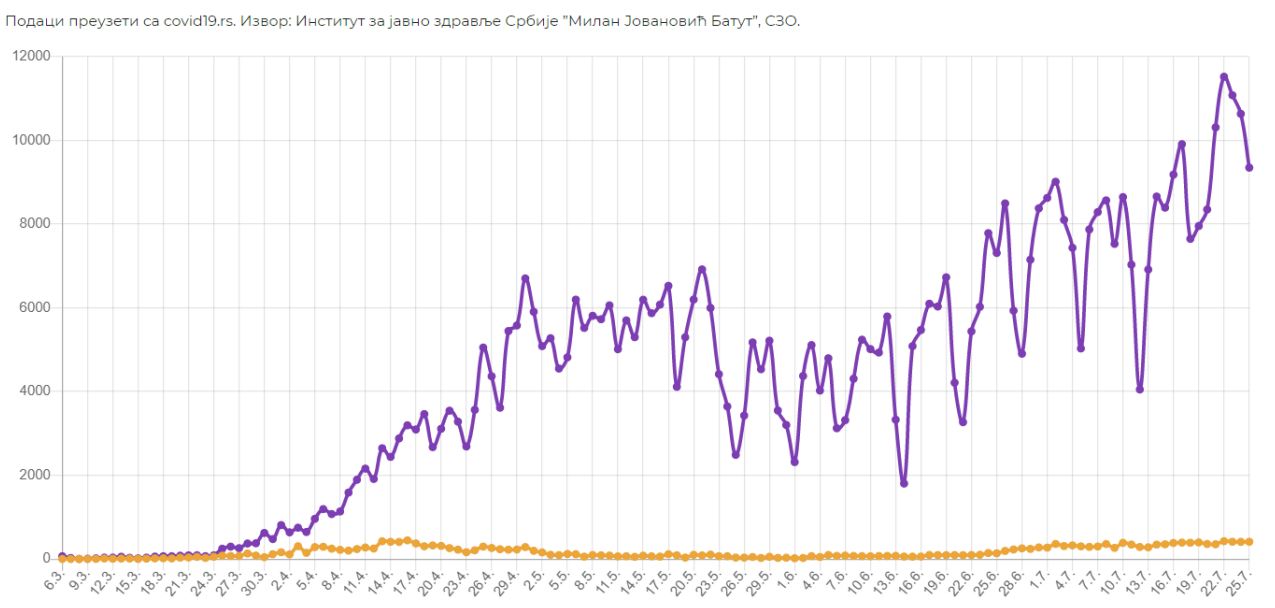

Figure 2 - Total number of tested (purple) and confirmed cases (orange) on daily basis, for Serbia, until July 25th, 2020 (Government of Republic of Serbia, 2020)

Pис. 2 -Общее количество протестированных (фиолетовый цвет) и подтвержденных (оранжевый цвет) случаев на ежедневной основе в Республике Сербия, до 25 июля 2020 года (Government of Republic of Serbia, 2020)

Слика 2 - Преглед односа укупног броја тестираних (љубичаста боја) и потврђених случајева (наранчаста боја) по данима, за Србију, до 25. јула 2020. (Government of Republic of Serbia, 2020)

In Serbia, the percentage of confirmed cases is not as high as in the Republic of Srpska, but the growth of tested, infected, and deceased is quite noticeable from the data provided by (Government of Republic of Serbia, 2020). Figure 2 shows a graphical representation of values corresponding to the number of confirmed cases (orange) and the number of conducted cases (purple), until July 25th, 2020. 
As previously mentioned, the rest of the world has not been spared from the testing kit shortage. Therefore, new protocols have been developed worldwide to reduce the scope of testing without affecting (at least not significantly) the quality and accuracy of the procedures (Eberhardt et al, 2020), (Mallapaty, 2020).

As a combinatorial procedure, group testing breaks down the identification task (identifying the defects in equipment, downtime in the use of communication channels, infected persons, etc.) into group tests instead of individual checks. Dorfman (Dorfman, 1943) was the first to describe this problem. Since then, different test schemes have been designed, including different types of tests as testing phases alternate (the so-called adaptive procedures). The idea itself has many applications in almost all areas of science: biology, computing, medicine, electrical engineering, data protection, etc. Interest in group testing was renewed after the launch of the famous Human Genome Project (Colbourn \& Dinitz, 2007) Some prominent examples where group testing is used in medicine are an examination of donated blood from American Red Cross donors (Dodd et al, 2002), testing for chlamydia and gonorrhea (Gaydos, 2005), and monitoring the mosquitoes which transmit the West Nile virus (White et al, 2001). Moreover, when it comes to testing for SARS-CoV-2 virus infection, (Gollier \& Gossner, 2020) have shown that even a very simplified approach, based on the bisection method, provides significant economic benefits.

This paper presents two simpler variants of non-adaptive group testing based on swab-sample aggregation, also known as the pooling design. Firstly, Hwang's generalized binary-splitting algorithm is presented. Afterward, the so-called matrix strategy is described. In the end, concluding remarks are given, reviewing the current situation.

\section{Hwang's generalized binary-splitting algorithm}

Here we will present Hwang's generalized binary-splitting algorithm. The pseudo-code is given in Algorithm 1. This approach can be used to cut resource costs in testing for SARS-CoV-2 infection (Ding-Zhu \& Hwang, 1993). The input variables are a statistical prediction of the number of people that will be tested $n$ and a statistical prediction of the number of confirmed cases $z$. The result should be a smaller number of tests needed to identify all infected individuals. 
According to (Ding-Zhu \& Hwang, 1993), the maximum number of tests $M_{t}$ when Algorithm 1 is used is

$$
M_{t}=\left\{\begin{array}{l}
n, \text { for } n \leq 2 m-2 \\
(s+2) z+p-1, \text { otherwise }
\end{array}\right.
$$

where $p<z$ is a unique nonnegative integer such that $m=2^{s} z+2^{s} p+\theta$, $0 \leq \theta<2^{s}$. If $\frac{n}{z}$ increases we have that $M_{t} \rightarrow z \log _{2} \frac{n}{z}$.

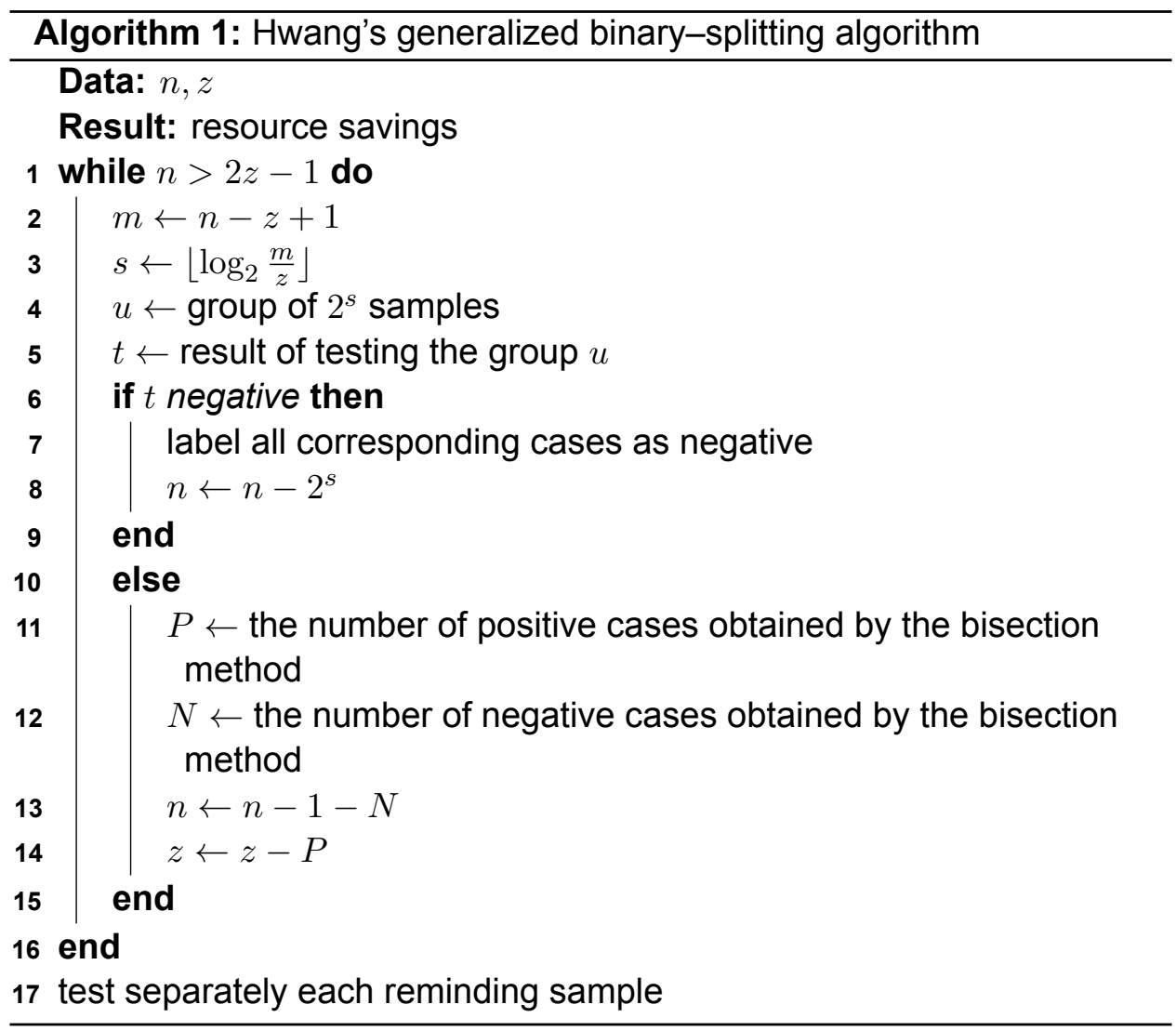

Example 1. Let there be a statistical forecast for the next day which says that the laboratory would need to take $n=100$ swab-samples. Consider two cases:

$(z=20)$ according to the Eq. (1) we have an estimation that 79 test will be needed at most, i.e. the laboratory will save at least 21 testing kits. 
$(z=2)$ according to Eq. (1) we have an estimation that 14 test will be needed at most, i.e. the laboratory will save at least 86 testing kits, much more compared to the previous case.

The downside of Hwang's generalized binary-splitting algorithm is that it may require more swabs from one individual. If we have a situation like in the case of $(z=20)$, in Example 1, we can see from the the Algorithm 1 that it will be necessary to combine the swab-samples of four people at the beginning. Suppose, for simplicity, that only one is infected in the group. This means that the identification of the infected one will be based on the bisection method. In other words, our tests to identify an infected person have the following order:

1. test the group of 4 samples;

2. test two groups of 2 samples;

3 . in the positive group test each sample separately.

As it can be noticed, it will be necessary to take three swabs from one person. The situation is getting complicated even more if the number of infected is very high, and $z$ is much lower than $n$. As often, laboratories cannot send technicians several times to take swabs, and it is not convenient for potentially infected people to come to the laboratory. Hwang's general binary-splitting algorithm can create certain operational problems. Moreover, taking three swabs from each person is already pushing the bounds of practicality. For this reason, a matrix strategy has been devised, in which two swabs are taken from each individual.

Remark 1. In case the estimated percentage of confirmed cases exceeds $50 \%$, it is not possible to make any resource cuts. Each swab-sample must be tested separately.

Remark 2. The presented Algorithm 1 does not take into account the accuracy of tests, i.e., the likelihood of obtaining false positive or false negative results is not considered.

Remark 3. The presented Algorithm 1 does not take into account whether there is a change in the accuracy of tests if a large number of samples are grouped. 


\section{Matrix strategy}

Another way to reduce the total number of tests, which will be presented here, is based on the so-called matrix (tabular) strategy. We can, for the sake of simplicity, assume that the number of people $n$ is the square of some natural number $k$, i.e., $n=k^{2}$. Phatarfod \& Sudbury (1994) were the first to propose this idea for high-throughput screening.

Basic matrix strategy (Algorithm 2). We take 2 (two) swab-samples from each person and form a square matrix of $M$ samples. Each entry $m_{i, j}$ of the matrix $M$ corresponds to one person, more precisely to a pair of swab-samples of that person. Rows and columns form groups of combined samples. With this, we have $2 k$ groups for the first phase of testing, which is $\frac{1}{2} k$ times less than the number in the case of individual checks. After the first phase (lines 1-2), we move on to the second phase (line 3).

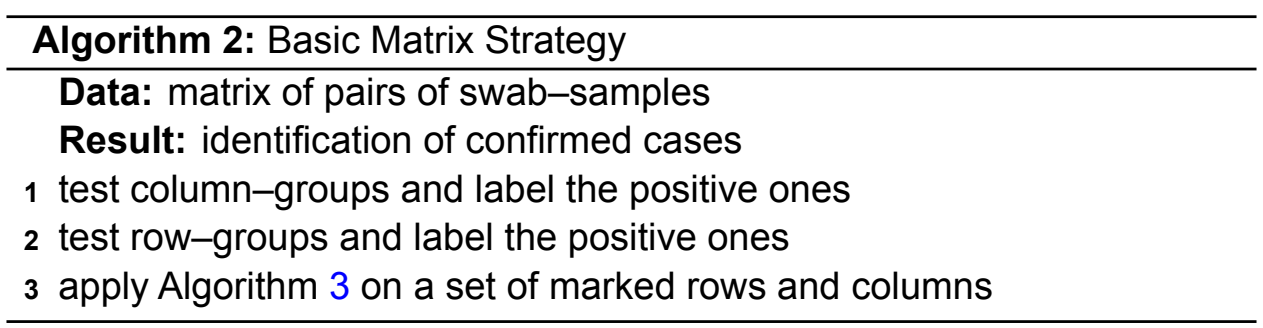

The following two situations are possible for the second phase if we get at least one positive result:

(1) if only one sample is positive, it is uniquely determined by the intersection of the positive column and the positive row;

(2) otherwise, the swab-samples of the individuals from the intersection of the positive columns and rows are retested.

The second case is the reason why it is necessary to take two swabsamples from each person.

The obvious problem with this approach, unlike with Hwang's generalized binary-splitting algorithm, is a possibility of a diagonal arrangement of samples of infected individuals (a technician is not aware of this because he/she does not know who is infected). Let's say that at the positions $m_{i, i}$, for $i \in\{1 \ldots, k\}$, everyone is infected. The total number of infected is $k$. Each column-group and row-group will be positive on the test of pooled 
samples. It follows from the previously described basic matrix strategy that we have to test all swab-samples on the intersections separately. In this case, it means all matrix entries. In other words, we need to test all swabsamples again, which in no way reduces the costs. Therefore, the maximum number of the basic matrix strategy tests for $n=k^{2}$ persons is $k^{2}+2 k$.

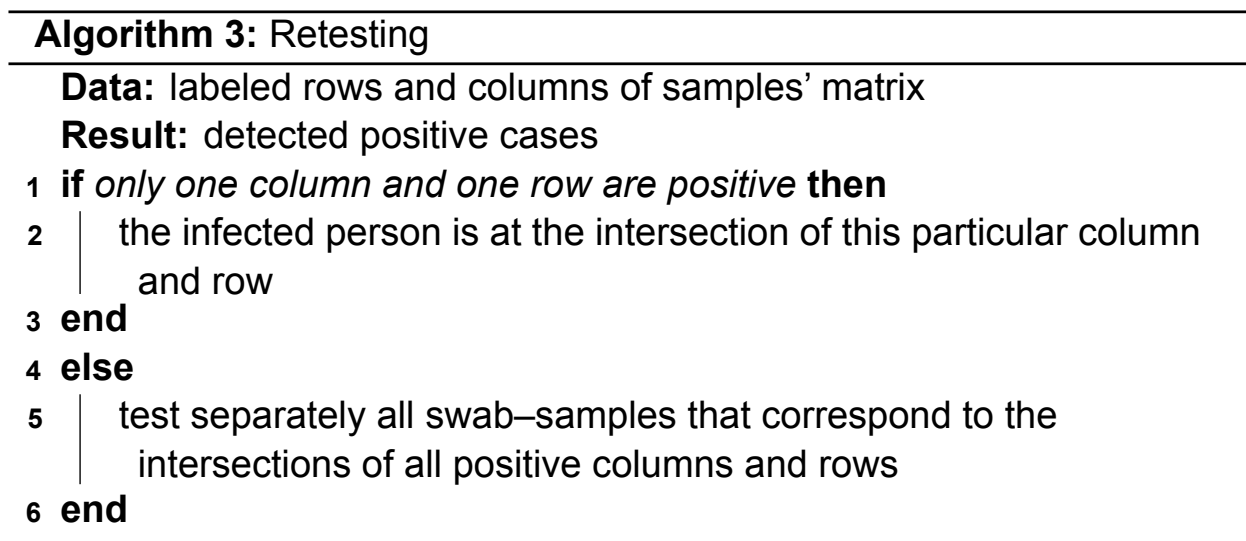

The basic matrix strategy can be improved by taking into account the experience of epidemiologists. For example, according to epidemiological analyses and field experience, swab-samples are classified into likely positive and likely negative ones. The use of additional information of this type was first studied by McMahan et al (2012). They considered two approaches:

- spiral design;

- gradient design.

This paper will present only the first approach-spiral design, particularly, its simplified variant.

The first probably positive sample pairs are clustered along one of the matrix "corners" - say the upper left, (in the above notation: $m_{1,1}$ ). Put the first pair of probably positive swab-samples at $m_{1,1}$. We put the other three in the positions $m_{2,1}, m_{2,2}, m_{1,2}$. Then, the next five are placed at positions $m_{3,1}, m_{3,2}, m_{3,3}, m_{2,3}, m_{1,3}$. The procedure is repeated until a set of probably positive samples is exhausted.

As it can be observed, this procedure leads to more expressed heterogeneity of the matrix. Then, moving from right to left, the first columngroups of the matrix will most likely show that they are negative, which gives us the right to write off their samples from further consideration. We stop at 
the first group-column that tests positive. Then we continue with the rows, from bottom to top, using the same idea. This can, roughly, eliminate a significant number of sample pairs. The described idea is represented by Algorithm 4.

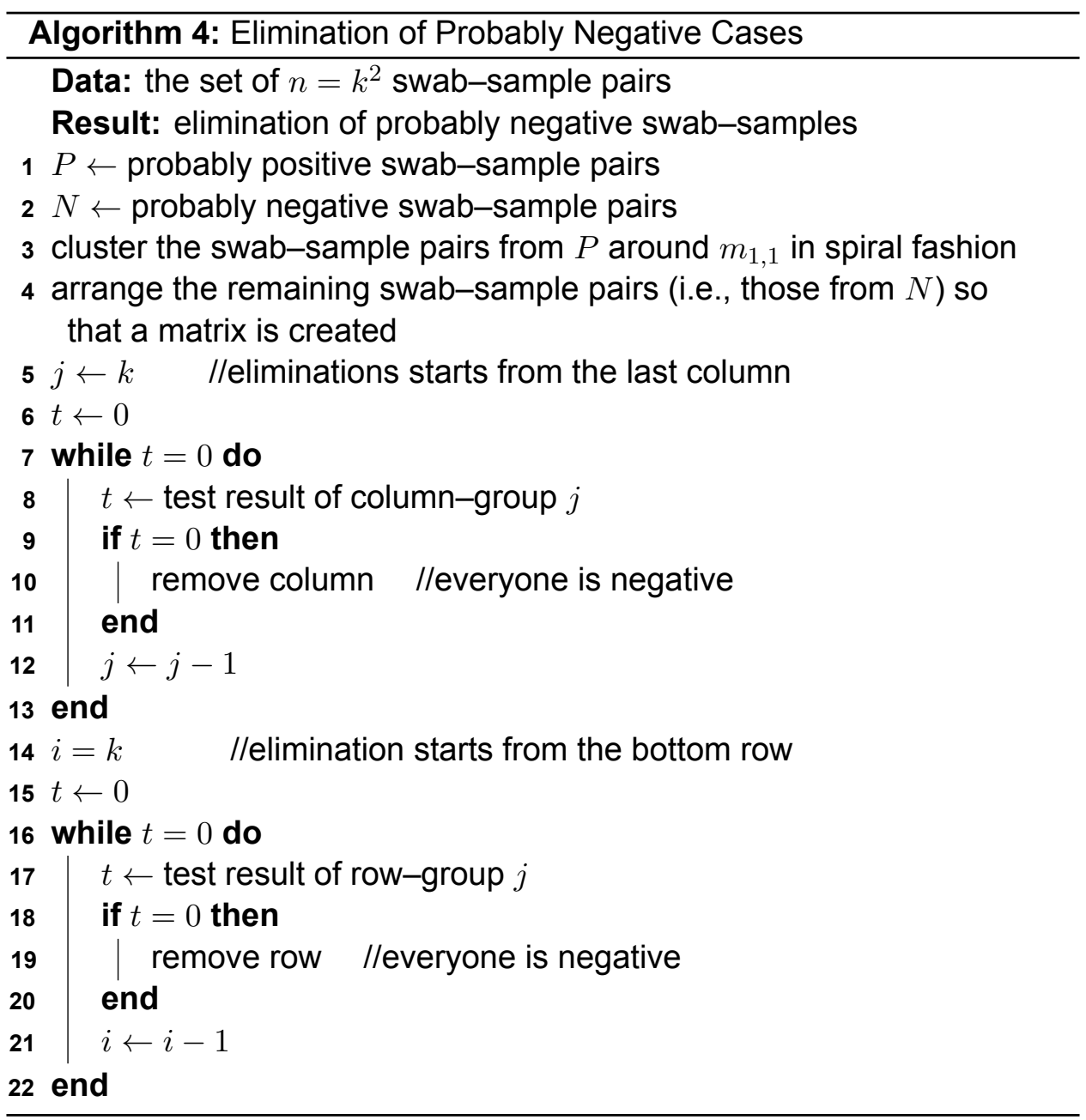

In Algorithm 4, the variables $P$ and $N$ are introduced, denoting sets of probably positive and probably negative samples, respectively. The variable $t$ has a binary domain, taking the value 0 if the test shows no infection (negative result) and 1 if it shows SARS-CoV-2 virus infection (positive result). 
Remark 4. In a gradient design, i.e, probably positive swab-sample pairs are clustered as columns, the elimination is performed only from right to left.

The diagonal elimination algorithm is applied to the rest of the matrix, obtained after the application of Algorithm 4. Before we describe the changes, we note that Algorithm 4 does not have to leave us a square matrix, i.e., the endpoint values of $i$ and $j$ do not have to be equal. Again, for simplicity, we consider a sub-matrix $M^{\prime}$ positioned along the upper left corner of the format $k^{\prime} \times k^{\prime}$, where $k^{\prime}=\min \{i, j\}$, for $i$ and $j$ as values returned by Algorithm 4.

\section{Algorithm 5: Diagonal Elimination}

Data: set of remaining swab-sample pairs; $i, j$ obtained by Algorithm 4

Result: identification of positive cases

$1 k^{\prime} \leftarrow \min \{i, j\}$

2 create a sub-matrix of samples $M^{\prime}$ with dimension $k^{\prime} \times k^{\prime}$

3 foreach $i \in\left\{1, \ldots, k^{\prime}\right\}$ do

$4 \quad t_{i, i} \leftarrow$ test the result of one swab-sample corresponding to the position $m_{i, k^{\prime}}$

if $t_{i, i}=0$ then

6

$t_{k^{\prime}-i, i} \leftarrow$ test the result of one swab-sample corresponding to the position $m_{k^{\prime}-i, i}$

$t_{i, k^{\prime}-i} \leftarrow$ test the result of one swab-sample corresponding to the position $m_{i, k^{\prime}-i}$

9 end

10 for each positive test result in the previous testing, label the corresponding columns and rows as positive

11 apply Algorithm 3 to the labeled rows and columns

In the first phase of eliminating diagonals, we test samples from one of the diagonals, say the main one. For each negative result at the position $m_{i, i}$ we test one sample from the corresponding positions on the counterdiagonal: $m_{k^{\prime}-i, i}$ and $m_{i, k^{\prime}-i}$. For each positive result, label the corresponding column and row as positive. Then test swab-samples from the intersec- 
tions of all positively labeled rows and columns (Algorithm 3). An overview of this procedure is given in Algorithm 5.

Here, too, as in the previous algorithm, the variable $t_{i, j}(\forall i, j \in$ $\left.\left\{1, \ldots, k^{\prime}\right\}\right)$ has a binary domain — takes the value 0 if the test shows no infection (negative result), and 1 if the test shows SARS-KoV-2 virus infection (positive result).

Remark 5. However, although this procedure should remove swabsamples of infected persons from a diagonal, we can observe that, if the statistical prediction of the percentage of infected persons is low enough, random distribution of samples of probably infected persons would rarely get into an undesirable situation. However, even the partial diagonal arrangement is unfavorable.

From the rest of all untested swab-sample pairs (including those that did not enter $M^{\prime}$ ), a new matrix $M^{\prime \prime}$ is formed. The diagonal elimination process can be repeated. How many times this will be done depends on the protocol of a particular laboratory and the costs cut estimate, given the daily scope of testing. This means that the elimination of diagonals can also be omitted.

Remark 6. After eliminating rows and columns in the first phase, the rest of the matrix does not necessarily have to be a square matrix, but we choose the largest quadratic sub-matrix.

Combining the previously described as a whole, we get Algorithm 6 improved matrix strategy. However, the proposed improvement of the basic matrix strategy does not bring the maximum number of tests below $k^{2}$, although such a large number is not expected in practice, especially if the percentage of infected concerning the number of tested is low. In other words, Hwang's generalized binary-splitting algorithm is theoretically a better approach than the matrix strategy. However, in practice, a matrix approach is used due to a smaller sampling volume.

Remark 7. The matrix strategy can be generalized to a multiphase tensor strategy, but this could lead to a rather impractical taking of many swabsamples from each person. 


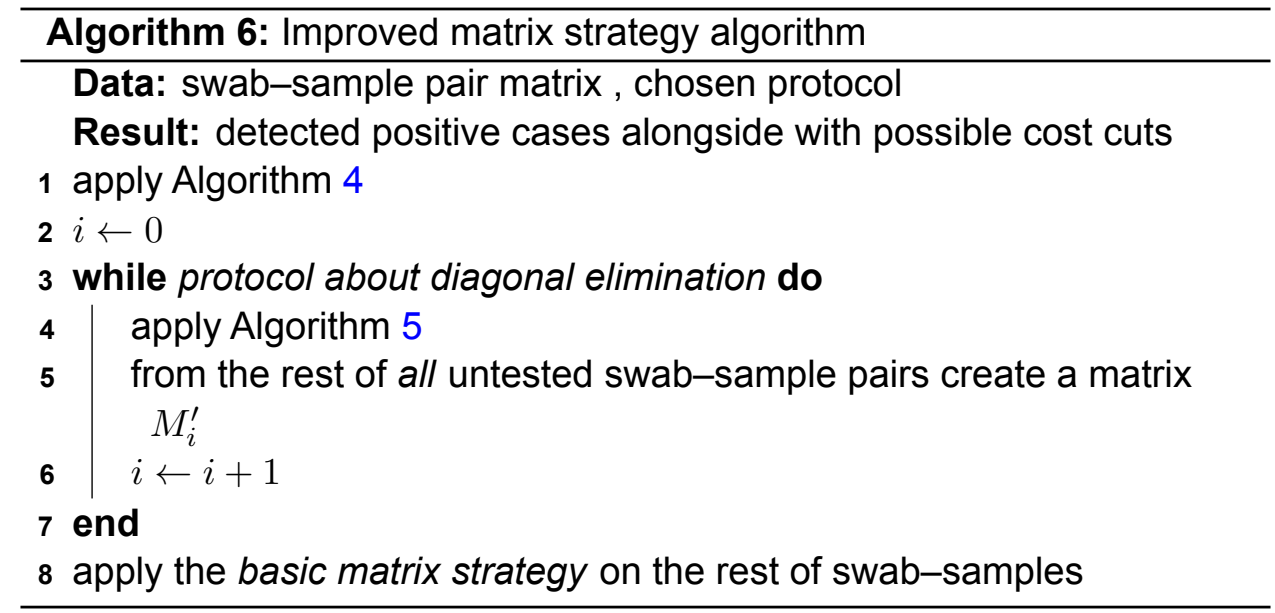

Remark 8. The initial matrix does not have to be square, but the case is considered in the algorithm, for simplicity. Otherwise, the natural choice for the matrix format is that the sum of columns and rows is the smallest possible.

Remark 9. Additional improvements may be considered, but are likely to affect applicability in practice.

Remark 10. The presented Algorithm 6 does not take into account the accuracy of the tests, i.e. the likelihood of obtaining false-positive or falsenegative results.

Remark 11. The presented Algorithm 6 does not take into account whether there is a change in the accuracy of tests if a large number of samples are combined.

\section{Concluding remarks}

The algorithms above provide a way to cut the resource costs if the number of confirmed cases is low enough compared to the number of conducted tests. The lower the percentage of infected, the more resources can be saved. However, this does not mean that timely action will not be useful if the percentage is high. On the contrary, even in that situation, adequate actions to save the resources are of considerable benefit.

Theoretically, more significant rationalization of resources is expected, first of all, when using Hwang's generalized binary-splitting algorithm, but 
it is not very practical due to possible excessive taking of swabs. Its use depends on situation assessment. In a way, the combination of both approaches could give satisfactory results, i.e. lead to considerable savings. In that case, we would have an adaptive approach.

Considering the current situation and a noticeable increase in those infected with the SARS-CoV-2 virus, it makes sense to consider the presented type of resource rationalization to increase the effectiveness of epidemiological measures. Also, it is essential to notice that these approaches are not exclusively related to RT-(q)PCR testing. They can be used equally successfully in mass serological testings.

\section{References}

-Blic. 2020. Nema testova, ima testova, u čemu je problem? Blic, 4 July [online]. Available at: www.blic.rs/vesti/drustvo/pcr-test-korona-virus-uzice-beograddr-predrag-kon/kbb68g9 (in Serbian) [Accessed 15 July 2020].

Colbourn, C.J. \& Dinitz, J.H. 2007. Handbook of Combinatorial Designs (2nd ed.). Boca Raton: Chapman \& Hall/ CRC. p. 574, Section 46: Pooling Designs

Ding-Zhu, Du. \& Hwang, F.K. 1993. Combinatorial group testing and its applications. Singapore: World Scientific. ISBN 978-9810212933.

Dodd, R., Notari, E. \& Stramer, S. 2002. Current prevalence and incidence of infectious disease markers and estimated window-period risk in the American Red Cross blood donor population. Transfusion, 42(8), pp.975-979. Available at: https://doi.org/10.1046/j.1537-2995.2002.00174.x.

Dorfman, R. 1943. The Detection of Defective Members of Large Populations. Annals of Mathematical Statistics, 14(4), pp.436-440. Available at: https://doi.org/ 10.1214/aoms/1177731363.

Eberhardt, J.N., Breuckmann, N.P. \& Eberhardt, C.S. 2020. Multi-Stage Group Testing Improves Efficiency of Large-Scale COVID-19 Screening. Journal of Clinical Virology, 128(art.number:104382). Available at: https://doi.org/10.1016/j.jcv.20 20.104382.

-Faculty of Electrical Engineering in Banja Luka. 2020. Ukupan broj slučajeva u Republici Srpskoj [online]. Available at: https://covid19.etfbl.net/ (in Serbian) [Accessed 15 July 2020].

Gaydos, C.A. 2005. Nucleic Acid Amplification Tests for Gonorrhea and Chlamydia: Practice and Applications. Infectious Disease Clinics of North America, 19(2), pp.367-386. Available at: https://doi.org/10.1016/j.idc.2005.03.006. 
Gollier, C. \& Gossner, O. 2020. Group testing against Covid-19. Covid Economics, 1(2), pp.32-42 [online]. Available at: https://www.tse-fr.eu/sites/default/ files/TSE/documents/doc/by/gollier/covid_economics.pdf [Accessed: 21 August 2020].

-Government of Republic of Serbia. 2020. COVID19 Statistics in Serbia [online] Available at: https://covid19.data.gov.rs/?locale=en [Accessed 25 July 2020].

-Government of Republic of Srpska. 2020. Zeljkovic: Nastavlja se trend pogoršanja epidemiološke situacije [online]. Available at: https://koronavirususr pskoj.com/nastavlja-se-trend-pogorsanja-epidemioloske-situacije/ (in Serbian) [Accessed 25 July 2020] (In the original: -Влада Републике Српске. 2020. Зељковић: Наставља се тренд погоршања епидемиолошке ситуације).

Mallapaty, S. 2020. The Mathematical Strategy That Could Transform Coronavirus Testing. Nature, 10 July [online]. Available at: https://www.nature.com/artic les/d41586-020-02053-6 [Accessed 15 July 2020].

McMahan, C.S., Tebbs, J.M. \& Bilder, C.R. 2012. Two-Dimensional Informative Array Testing. Biometrics, 68(3), pp.793-804. Available at: https://doi.org/10.1 111/j.1541-0420.2011.01726.x.

Pfeiffer, S., Anderson, M. \& van Woerkom, B. 2020. Despite Early Warnings, U.S. Took Months To Expand Swab Production For COVID-19 Test. NPR [online]. Available at: https://www.npr.org/2020/05/12/853930147/despite-early-warning s-u-s-took-months-to-expand-swab-production-for-covid-19-te [Accessed 15 July 2020].

Phatarfod, R.M. \& Sudbury, A. 1994. The use of a square array scheme in blood testing. Statistics in Medicine, 13(22), pp.2337-2343. Available at: https: //doi.org/10.1002/sim.4780132205.

Sanche, S., Lin, Y., Xu, C., Romero-Severson, E., Hengartner, N. \& Ke, R. 2020. High Contagiousness and Rapid Spread of Severe Acute Respiratory Syndrome Coronavirus 2. Emerging Infectious Diseases 26(7), pp.1470-1477. Available at: https://dx.doi.org/10.3201/eid2607.200282.

White, D., Kramer, L., Backenson, P., Lukacik, G., Johnson, G., Oliver, J., Howard, J., Means, R., Eidson, M., Gotham, I., Kulasekera, V. \& Campbell, S. 2001. Mosquito surveillance and polymerase chain reaction detection of West Nile Virus, New York state. Emerging Infectious Diseases, 7(4), pp.643-649. Available at: https://dx.doi.org/10.3201/eid0704.017407. 


\section{ЭКОНОМИЯ РЕСУРСОВ ДЛЯ ТЕСТИРОВАНИЯ ПУТЕМ ОБЪЕДИНЕНИЯ ОБРАЗЦОВ}

Димитрие Д. Чвокич

Университет в г. Баня-Лука, Факультет естественных наук и математики, г. Баня-Лука, Республика Сербская, Босния и Герцеговина

РУБРИКА ГРНТИ: 27.00.00 МАТЕМАТИКА:

27.47.19 Исследование операций,

27.47.17 Математическая теория информации, 27.41.41 Алгоритмы решения задач вычислительной и дискретной математики

ВИД СТАТЬИ: оригинальная научная статья

Резюме:

Введение/цель: Цель алгоритмов группового тестирования заключается в обеспечении рационального использования ресурсов. Вследствие такого подхода можно надеяться на повышение эфрфективности массового скрининга меmодом RT(q)PCR для выявления зараженных вирусом CAPCKoB2.

Методы: В данной статье представлены два варианта неадаптивных групповых подходов к тестированию: обобщенный алгоритм двоичного расщепления Венга и стратегическая матрица.

Результаты: В статье обсуждаются положительные и отрицательные стороны обоих подходов и даны оценки максимального количества тестов. Стратегическая матрица представлена с определенной модификацией, которая снижает вышеупомянутую оценку, но не сильно влияет на сложность процедуры, что делает ее особенно пригодной для применения.

Выводы: Учитывая текущую ситуацию, имеет смысл рассмотреть этот вид рационализации ресурсов с целью повышения эфрфективности противоэпидемических мероприятий.

Ключевые слова: экономия путем объединения образцов, групповое тестирование, обобщенный алгоритм двоичного расщепления Венга, стратегическая матрица, COVID19, SARSCoV2. 


\section{УШТЕДА ТЕСТОВА УДРУЖИВАЊЕМ УЗОРАКА}

Димитрије Д. Чвокић

Универзитет у Бањој Луци, Природно-математички факултет, Бања Лука, Република Српска, Босна и Херцеговина

ОБЛАСТ: математика

ВРСТА ЧЛАНКА: оригинални научни рад

Сажетак:

Увод/циљ: Сврха алгоритама групног тестирања јесте да обезбједе рационализацију ресурса. Стога, очекује се да се њиховим коришћењем могу, такође, остварити одређене уштеде при масовном тестирању RT(q)PCR методом ради идентификације заражених вирусом CAPCКоB2.

Методе: Предочена су два приступа неадаптивног групног тестирања заснованог на удруживању узорака, у англојезичној литератури познатом као pooling design: Хвангов алгоритам уопитеног цијепања и матрична стратегија.

Резултати: Уз дискусију добрих и лоших страна наведене су и оијене максималног броја тестова. Матрична стратегија представљена је својеврсном модификацијом која смањује поменуту оијену, а, с друге стране, не утиче много на комплексност процедуре, што је значајно за њену примјену у пракси.

Закључак: Узимајући у обзир тренутну ситуацију, има смисла разматрати овакву врсту рационализације ресурса, ради повећања ефикасности епидемиолошких мјера.

Кључне речи: уштеда удруживањем узорака, групно тестирање, Хвангова уопитена бисекција, матрична стратегиja, COVID-19, CAPC-KoB-2.

Paper received on / Дата получения работы / Датум пријема чланка: 26. 08. 2020. Manuscript corrections submitted on / Дата получения исправленной версии работы / Датум достављања исправки рукописа: 11. 10. 2020.

Paper accepted for publishing on / Дата окончательного согласования работы / Датум коначног прихватања чланка за објављивање: 13. 10. 2020. 
(C) 2019 The Author. Published by Vojnotehnički glasnik / Military Technical Courier (http://vtg.mod.gov.rs, http://втг.мо.упр.срб). This article is an open access article distributed under the terms and conditions of the Creative Commons Attribution license (http://creativecommons.org/licenses/by/3.0/rs/).

(c) 2019 Автор. Опубликовано в "Военно-технический вестник / Vojnotehnički glasnik / Military Technical Courier" (http://vtg.mod.gov.rs, http://втг.мо.упр.срб). Данная статья в открытом доступе и распространяется в соответствии с лицензией "Creative Commons" (http://creativecommons.org/licenses/by/3.0/rs/).

(c) 2019 Аутор. Објавио Војнотехнички гласник / Vojnotehnički glasnik / Military Technical Courier (http://vtg.mod.gov.rs, http://втг.мо.упр.срб). Ово је чланак отвореног приступа и дистрибуира се у складу са Creative Commons лиценцом (http://creativecommons.org/licenses/by/3.0/rs/).

(c) () 